\title{
Anaerobic Digestion of Food Wastes under Different Concentrations of Total Solids
}

\author{
${ }^{1}$ El-Akshar Y.S. and ${ }^{2}$ Yasmin H.S. Faisal
}

${ }^{I}$ Soils, Water and Environment Research Institute, Agricultural Research Center, P.O. 12112, Giza, Egypt

${ }^{2}$ The American University in New Cairo, Cairo, Egypt.

Received: 20 April 2020 / Accepted 20 July 2020 / Publication date: 30 July 2020

\begin{abstract}
Fourth different concentrations of total solids B1, B2, B3, and B4 were prepared using food wastes, calcium carbonate and starter in four digesters to biogas production. The data showed colonies of total coliform bacteria were not detected the $14^{\text {th }}$ day. Fecal coliform bacteria were not detected through the $7^{\text {th }}$ day. Meanwhile, counts of Salmonella and Shigella were rapidly decreased throughout the anaerobic digestion period to be completely undetected onthe $14^{\text {th }}$ and $21^{\text {st }}$ days for all fomenters. A digested slurry of B3 and B4 exhibited (the highest) records of volatile fatty acids compared to the digested slurry of $\mathrm{B} 1$ and $\mathrm{B} 2$, respectively. The $\mathrm{pH}$ values were favorable to biogas generation and methane production, this was observed at different fermentation periods in both B1 and B2. The toxicity of $\mathrm{pH}$ is more pronounced in the fermentors, especially in B3 and B4. Accumulation of ammonia during anaerobic fermentation was $385.52,462.68,870.24$ and $925.88 \mathrm{ppm}$ in B1, B2, B3, and B4, respectively where it was not reach to level of toxicity or even inhibitive of methanogenic bacteria. The digested slurry of B4 exhibited the highest recorded of volatile fatty acids compared to the digested slurry of other digestions .The Cumulative biogas and methane were higher in B2, B1 than $\mathrm{B} 3$, and $\mathrm{B} 4$. Biogas and methane production rates $(\mathrm{L} / \mathrm{Kg})$ volatile solids consumed were 958.79,755.76, 213.19 and 141.76 for biogas, meanwhile methane was 501.57, 367.82, 25.36 and 13.41 in digesters B2, B1, B3 and B4, respectively.
\end{abstract}

Keywords: Anaerobic digestion, Biogas, Food wastes, Total solids

\section{Introduction}

The environmental challenges related to the global population growth and the global energy demand are continuously promoting research efforts to develop innovative technologies aimed at producing energy from non-conventional sources (Lay et al., 1997 and Mussoline et al., 2013). Food wastes are variably sourced from residential, commercial establishments, institutional and industrial activities, its characterized with high contents of moisture (about $70-80 \%$ of water) and biodegradable organics (about $18-31 \%$ of total solids) and account for $40-50 \%$ of the weight of municipal solid waste (MSW), according to the eating behaviors of populations in various countries (Zhang et al., 2011 and 2013) which make the reuse of it is a favorable option for energy recovery and cost-effective municipal solid waste reduction using anaerobic digestion technology. In Egypt, food wastes are generated at an ever-increasing with the excessive population growth and their activities which attains about $50 \%$ vegetables and fruits, $40 \%$ fish wastes and $30 \%$ milk, in addition to amount of wheat losses and waste reaches 1.5 million tons/per annual (Elmenofi et al., 2015).

Anaerobic digestion is biochemically processed in a successive multi-stagesby which the biodegradable and high molecular weight organic matter succumb to hydrolysis acidogenesis, and methanogenesis and each is metabolically functioned through the activities of fermentative bacteria, producing small molecular weight substrates (Veeken and Hamelers, 1999; Guo et al., 2014). Based on the total solids (TS) content of feedstocks, three main types of anaerobic digestion technologies have been developed including 1) Conventional wet ( $\leq 10 \%$ TS); 2) Semi-dry (10-20\% TS) and 3) Modern dry ( $\geq 20 \% \mathrm{TS}$ ) processes.

The dry anaerobic digestion, pronounced as "high-solids" technology, has become attractive and was applied widely because it requires smaller reactor volume, lower energy requirements for heating, less material handling, and so on (Forster-Carneiro et al., 2008; Duan et al., 2012). The TS contents of solid waste influences anaerobic digestion performance, especially biogas and methane

\footnotetext{
Corresponding Author: El-Akshar Y.S., Soils, Water and Environment Research Institute, Agricultural Research Center, Giza, Egypt. E-mail: yasser671@gmail.com
} 
production efficiency (Pavan et al., 2000). Abbassi-Guendouz et al., (2012) found that the methane production slightly decreased with TS concentrations increasing from 10 to $25 \%$ TS in batch anaerobic digestion of cardboard under mesophilic conditions.

The present study aimed to investigate the effect of different total solid concentrations on biogas production from food wastes by using a batch system.

\section{Materials and Methods}

\section{Materials}

\subsection{Food wastes:}

Large quantities of food wastes (FW) were collected from Kentucky Fried Chicken (KFC) restaurant, El-Tahrir, Cairo Governorate, Egypt. Random samples from the collected wastes were picked up to determine their chemical analysis as shown in Table (1).

\subsection{Starter:}

Starter was taken from an old operating biogas digester at Training Center for Recycling of Agricultural Residues (TCRAR), Agric., Res. Center at Moshtohor, Kalubia Governorate. Representative samples of FW and the starter were taken and analyzed for several chemical parameters. The results are shown in Table (1).

Table 1: Chemical and physical characteristics of food wastes and starter

\begin{tabular}{lcc}
\hline Character & Food wastes & Starter \\
\hline Moisture content (\%) & 74.10 & 99 \\
Total solids (\%) & 25.90 & 1.00 \\
pH 1:10 raw material: water (w/v) & 4.60 & 7.66 \\
EC1:10 raw material: water (dS.m $\mathbf{- 1}^{\mathbf{1}}$ ) & 2.50 & 10.09 \\
Ammoniacal -N (ppm) & 366 & 125.00 \\
Volatile fatty acids (meq/kg fresh weight) & 54 & 26 \\
Volatile solids (VS)\% & 94.25 & 30.00 \\
Organic carbon (OC) \% & 54.67 & 17.4 \\
Total nitrogen (N)\% & 2.25 & 1.35 \\
C/N ratio & $24.30: 1$ & $12.89: 1$ \\
Total phosphorus (\%) & 0.76 & 0.50 \\
Total potassium (\%) & 1.05 & 0.65 \\
\hline
\end{tabular}

\subsection{A laboratory bath experiment}

Twelve units of batch anaerobic digestion were used in this study. Each digester had a total volume of 3 liters with an active volume 2.50 liters Figure (1).

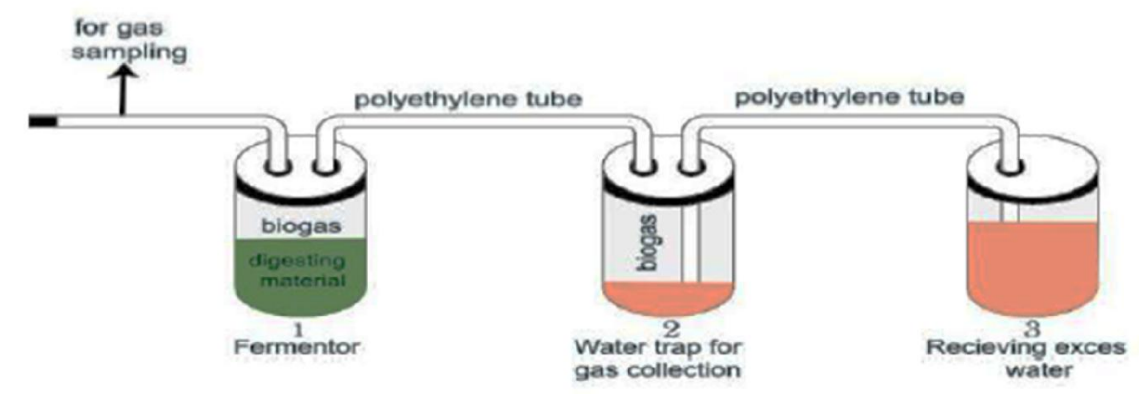

Fig. 1: Laboratory biogas digester units

\subsection{Experimental procedures}

A Laboratory batch experiment using a conventional reactor was conducted to study the productivity of biogas from food wastes under different concentrations of total solids, namely 
2.5,5.0,7.5, and $10.0 \%$. Therefore, appropriate weights of well mixed with fresh $25 \%(\mathrm{~V} / \mathrm{V})$ of starter from active digester volume for each digester. Calcium carbonate was added also at the rate of $2 \%$ of total solids to serve as a buffer. Initially, digested slurries were adjusted to $\mathrm{pH} 7.0$ by $0.1 \mathrm{~N}$ solution of $\mathrm{KOH}$ as follows:

B1: Total solids adjusted $2.5 \%$ from food wastes $+25 \%$ starter $(\mathrm{V} / \mathrm{V})$ of active digester volume $+2 \%$ $\mathrm{CaCO}_{3}$ from $\mathrm{TS}$.

B2: Total solids adjusted 5\% from food wastes $+25 \%$ starter $(\mathrm{V} / \mathrm{V})$ of active digester volume $+2 \%$ $\mathrm{CaCO}_{3}$ from $\mathrm{TS}$.

B3: Total solids adjusted 7.5\% from food wastes $+25 \%$ starter $(\mathrm{V} / \mathrm{V})$ of active digester volume $+2 \%$ $\mathrm{CaCO}_{3}$ from TS.

B4: Total solids adjusted $10 \%$ from food wastes $+25 \%$ starter $(\mathrm{V} / \mathrm{V})$ of active digester volume $+2 \%$ $\mathrm{CaCO}_{3}$ from TS.

All treatments were run in triplicates. Therefore, 12 fomenters were constructed, sealed, incubated growth champer at $35 \pm 1 \mathrm{C}^{\mathrm{o}}$ for long 42 days. Samples were taken weekly from the fomenters for determined $\mathrm{pH}$, ammoniacal nitrogen $\left(\mathrm{NH}_{4}-\mathrm{N}\right)$, total volatile fatty acids (VFAs), total solids (TS), volatile solids (VS), Organic carbon (OC) \%, total nitrogen (TN), total phosphorus (TP) and total potassium (TK). Also, total and fecal coliform (as an indicator of pathogenic bacteria) meanwhile, pathogen bacteria representing Salmonella and Shigella were assayed in addition to, the gas yield was daily measured, while methane and carbon dioxide were measured every 3 days.

\section{Methods}

Daily biogas yield was estimated according to Maramba et al. (1978). Methane content and individual volatile fatty acids were determined by gas-liquid chromatography according toWujick and Jewell (1980).Carbon dioxide content was estimated using Orsat's apparatus as the method described by Hamilton and Stephen (1964). Total solids, volatile solids, organic carbon, total phosphorus, total potassium, and total volatile fatty acids were determined according to the stranded method byAPHA (1992).The hydrogen ion concentration was directly measured by1:5 sample: water mixture, using a glass electrode $\mathrm{pH}$ meter. Ammoniacal nitrogen was determined by the Kjeldahl method according to Black et al. (1981).

Coliform group bacteria (total \& fecal) were counted on MacConkey's bile salt agar medium and Salmonella and Shigella were counted on S.S agar medium according to (Difco Manual, 1977).

\section{Statistics analysis}

The experiment was arranged in a completely randomized block design and data were analyzed according to methods described by Snedecor and Cochran (1980). The averages were compared using L.S.D. values.

\section{Results and Discussion}

\section{Survival of pathogenic bacteria}

The total and fecal coliform group as well as Salmonella \& Shigella (SS) were presented in Table (2). The highest counts of total, fecal coliform group and Salmonella \& Shigella were in the starting experiment where, total coliform bacteria range from 2.10 to $13.20 \times 10^{3} \mathrm{cfu} / \mathrm{g}$, meanwhile fecal coliform was range from 0.11 to $3.20 \times 10^{2} \mathrm{cfu} / \mathrm{g}$ while, Salmonella and Shigella were ranged from 3 to $20 \times 10^{2} \mathrm{cfu} / \mathrm{g}$ during the zero time. These counts were rapidly decreased as anaerobic digestion progressed.

Also, data showed that during the first part of the fermentation period numbers of either total or fecal coliform groups were higher than Salmonella and Shigella groups. The colonies of total coliform bacteria were not detected at the 3-week sample but the fecal coliform bacteria was not appeared at the second week. Also, Salmonella and Shigella were not detected after second week in B1, B2 and $\mathrm{B} 3$ treatments. In contrary, B4 achieved $1.2 \times 10^{-1} \mathrm{cfu} / \mathrm{g}$ during the second week then pathogen bacteria not detected after this period (second week) in all treatments anaerobic digestion. 
These results were almost in agreement with El-Akshar (2000), He found that the fecal coliform bacteria are almost completely absent in the end product resulting from dry anaerobic fermentation. Also, Estefanous et al. (2010) and El-Khayat (2014) found that the colonies of total coliform bacteria were not detected after 6weeks sample but the undetected of faecal coliform bacteria was achieved after the 5 weeks. Salmonella \&Shigella were not detected at the fifth week of fermentation by increasing the anaerobic fermentation time of municipal solid waste.

Table 2: Changes in the counts of total, fecal coliform and pathogenic bacteria (cfu/g.DW) during of anaerobic digestion of food wastes during 6 weeks.

\begin{tabular}{|c|c|c|c|c|c|c|c|}
\hline \multirow[b]{2}{*}{ Treatments } & \multicolumn{7}{|c|}{ Periods (week) } \\
\hline & $\mathbf{0}$ & 1 & 2 & 3 & 4 & 5 & 6 \\
\hline \multicolumn{8}{|c|}{ Total coliform $\left(\times 10^{-3}\right) \mathrm{cfu} / \mathrm{g}$} \\
\hline$\overline{\text { B1 }}$ & 2.10 & 0.10 & 0.08 & ND & ND & ND & ND \\
\hline B2 & 7.25 & 0.85 & 0.19 & ND & ND & ND & ND \\
\hline B3 & 11.52 & 1.11 & 0.93 & ND & ND & ND & ND \\
\hline B4 & 13.20 & 2.10 & 1.10 & ND & ND & ND & ND \\
\hline \multicolumn{8}{|c|}{ Faecal coliform $\left(\times 10^{-2}\right) \mathrm{cfu} / \mathrm{g}$} \\
\hline B1 & 0.11 & 0.01 & ND & ND & ND & ND & ND \\
\hline B2 & 0.75 & 0.05 & ND & ND & ND & ND & ND \\
\hline B3 & 1.50 & 0.80 & ND & ND & ND & ND & ND \\
\hline B4 & 3.20 & 1.32 & ND & ND & ND & ND & ND \\
\hline \multicolumn{8}{|c|}{ Salmonella \& Shigella $\left(\times 10^{-1}\right) \mathrm{cfu} / \mathrm{g}$} \\
\hline$\overline{\text { B1 }}$ & 3.00 & ND & ND & ND & ND & ND & ND \\
\hline B2 & 10.00 & 2.00 & ND & ND & ND & ND & ND \\
\hline B3 & 14.00 & 2.80 & ND & ND & ND & ND & ND \\
\hline B4 & 20.00 & 11.00 & 1.20 & ND & ND & ND & ND \\
\hline
\end{tabular}

- ND: Not detected

\section{Physical and Chemical Parameters}

\subsection{Volatile fatty acids}

The present results in Table (3). show that the volatile fatty acids in the digesting slurries where, its represent the majorportion of the intermediate substrate from which the methane generated. In this respect, VFAs increased gradually until the third week it had been shown 50.90 and 60.40 $\mathrm{meq} / \mathrm{L}$ in fomenters contained B1 and B2,respectively.

Table 3: Changes of volatile fatty acids, $\mathrm{pH}$, and ammoniacal-nitrogen during anaerobic digestion periods.

\begin{tabular}{|c|c|c|c|c|c|c|c|}
\hline \multirow{3}{*}{ Treatments } & \multicolumn{7}{|c|}{ Periods (weeks) } \\
\hline & $\mathbf{0}$ & 1 & 2 & 3 & 4 & 5 & 6 \\
\hline & \multicolumn{7}{|c|}{ VFAs (meq/L) } \\
\hline B2 & 11.30 & 30.62 & 40.50 & 60.40 & 52.30 & 46.10 & 37.00 \\
\hline B3 & 21.45 & 68.10 & 120.00 & 150.90 & 180.25 & 190.85 & 200.60 \\
\hline B4 & 27.60 & 75.20 & 156.00 & 166.00 & 200.00 & 220.00 & 232.25 \\
\hline LSD $5 \%$ & \multicolumn{7}{|c|}{$\mathrm{pH}$} \\
\hline B1 & 7.04 & 6.45 & 6.12 & 6.62 & 6.95 & 7.50 & 8.20 \\
\hline B2 & 6.95 & 6.31 & 6.00 & 6.50 & 6.90 & 7.00 & 7.40 \\
\hline B3 & 6.76 & 5.40 & 5.10 & 5.00 & 5.30 & 4.90 & 5.80 \\
\hline B4 & 6.50 & 5.00 & 4.80 & 4.50 & 4.70 & 4.85 & 5.60 \\
\hline B2 & 86.64 & 150.60 & 275.35 & 320.10 & 447.44 & 580.20 & 462.68 \\
\hline B3 & 116.48 & 225.00 & 322.00 & 411.01 & 529.31 & 610.11 & 870.24 \\
\hline B4 & 152.32 & 280.05 & 420.60 & 521.00 & 688.32 & 710.25 & 925.88 \\
\hline LSD $5 \%$ & 4.2599 & 5.5609 & 5.0189 & 4.374 & 5.5108 & 5.336 & 6.216 \\
\hline
\end{tabular}


Thereafter, VFAs values were dropped gradually to end of digestion period as due to its consumption by the methane-forming bacteria. On the other hand, the accumulation of VFAs in the other fermenters (B3 and B4) continued towards the end of the experiment to reach maximum values 200.60 and $232.25 \mathrm{meq} / \mathrm{L}$., respectively. Zhang et al. (2014); El-Khayat (2019) reported that the concentration of VFAs decreased by increasing the fermentation periods this may be due to the VFAs are converting into $\mathrm{CO}_{2}$ and $\mathrm{CH}_{4}$ by methane bacteria.

\subsection{Hydrogen Ion Concentration (pH)}

The changes in $\mathrm{pH}$ values in the four fermenters at different anaerobic digestion periods observed in Table (3) shown an inverse high level of VFAs and low values of $\mathrm{pH}$ were recorded at the same time. When the consumption of VFAs was started, the $\mathrm{pH}$ values were turned to increase towards alkalinity as shown in the fermentors contained $\mathrm{B} 1$ and $\mathrm{B} 2$, this may be due to $\mathrm{CaCO}_{3}$ buffer in the initial wastes' mixture and the natural decomposition of this materials. While the toxicity of $\mathrm{pH}$ is more pronounced in the fermentors loaded with high concentrations of total solids B3 and B4. These results were similar to the reported by Kvasauskas and Baltrenas (2008) who found that the $\mathrm{pH}$ changed from 6.6 to 7.10 in the course of sewage sludge biodegradation. Also, Budiyono et al. (2010) found that there was an increase in $\mathrm{pH}$ before and after digestion. The same trend was obtained by El-Khayat (2014)who found that the $\mathrm{pH}$ values increased at the end of anaerobic digestion.

\subsection{Ammoniacal- Nitrogen}

Data of ammoniacal - nitrogen (Table 4) indicate that ammoniacal -nitrogen showed a gradual increase in $\mathrm{NH}_{4}-\mathrm{N}$ levels to reach a maximum after 5 weeks of incubation and then declined in $\mathrm{B} 1$ and $\mathrm{B} 2$, while $\mathrm{B} 3$ and B4 exhibited a continual increase by the time of digestion. The level of ammoniacal - nitrogen was directly proportional to the totalsolid's concentration of the digestion slurry.

There is a negative relation between the level of ammoniacal - nitrogen and the $\mathrm{pH}$. However, the maximum level of $\mathrm{NH}_{4}-\mathrm{N} 925.88 \mathrm{ppm}$ was exhibited by B4. Still level of ammonia is not injurious for the digestion and methanogenic bacteria. These results are agreement with those reported by ElAkshar (2000) and Estefanous et al. (2010). They found that the concentration of $\mathrm{NH}_{4}-\mathrm{N}$ increases alone with anaerobic digestion to reach its high values after four weeks, being $1200 \mathrm{mg} / \mathrm{L}$, and then decreased to $325 \mathrm{ppm}$ after eight weeks of digestion.

\subsection{Total solids, volatile solids, and total nitrogen.}

Total solid (TS), volatile solids (VS), and total nitrogen (TN) were determined at the initial and final of the experimental period in Table (4).

Table 4: Changes of total, volatile solids and total nitrogen content during anaerobic digestion of food wastes during 42 days.

\begin{tabular}{cccccccccc}
\hline & \multicolumn{3}{c}{$\begin{array}{c}\text { Total solids } \\
\text { (g/digester) }\end{array}$} & \multicolumn{3}{c}{$\begin{array}{c}\text { Volatile solids } \\
\text { (g/digester) }\end{array}$} & \multicolumn{2}{c}{$\begin{array}{c}\text { Nitrogen content } \\
\text { (g/digester) }\end{array}$} \\
\cline { 2 - 10 } Treatments & Initial & Final & $\begin{array}{c}\text { Losses } \\
\text { \% }\end{array}$ & Initial & Final & $\begin{array}{c}\text { Losses } \\
\text { \% }\end{array}$ & Initial & Final & $\begin{array}{c}\text { Losses } \\
\text { \% }\end{array}$ \\
\cline { 2 - 11 } & 62.50 & 24.71 & 60.46 & 51.96 & 14.17 & 72.73 & 1.01 & 0.43 & 57.43 \\
B1 & 125.00 & 86.90 & 30.48 & 110.10 & 72.00 & 34.60 & 2.16 & 1.56 & 27.78 \\
B2 & 187.50 & 134.26 & 28.39 & 168.94 & 115.70 & 31.51 & 3.47 & 2.64 & 23.92 \\
B3 & 250.00 & 182.14 & 27.14 & 227.75 & 159.89 & 29.80 & 5.00 & 3.79 & 24.20 \\
B4 & 4.43 & 4.77 & 5.10 & 5.60 & 5.05 & 5.26 & 2.67 & 1.15 & 4.69 \\
\hline LSD 5\% & & & & & & &
\end{tabular}

Data clearly show that the concentration of the above-mentioned parameters decreased throughout the digestion course. The loss percentages of total solids were $60.46,30.48,28.39$ and $27.14 \%$ in B1, B2, B3, and B4, respectively. Also, the loss percentages of volatile solids were 72.73 , $34.60,31.51$ and 29.80 in B1, B2, B3, and B4, respectively. Meanwhile, the loss percentages of total nitrogen were 57.43, 27.78, 23.92 and 24.20 in B1, B2, B3, and B4, respectively. Such decrements recorded in this study especially in total and volatile solids occurred in the form of gases and water. Dinsdale et al. (1996) reported that a 58\% reduction in volatile solids was observed in the batch system during anaerobic digestion of wastewater containing significant levels of coffee grounds. In 
this respect, Estefanous et al. (2010) and El-Khayat (2014)found that during anaerobic digestion the total solids, volatile solids, and total nitrogen were decreased due to a high substrate conversion rates to biogas and methane in the digestion process. Ugwuoke et al. (2015) mentioned that the total solid of any given biogas feedstock specifically contributes to the execution of the system and ltwlaccumulative of biogas amid anaerobic digestion. There is a reverse connection between the total solid content and an accumulative of biogas.

\subsection{Total nitrogen, phosphorus and total potassium}

Changes in concentrations of total nitrogen, phosphorus and potassium were determined in the initial and the final of the anaerobic digestion period, the obtained results are tabulated in Table (5).

Table 5: The concentration of total nitrogen, phosphorus and potassium initial and final anaerobic digestion of food wastes.

\begin{tabular}{|c|c|c|c|c|c|c|}
\hline \multirow[t]{2}{*}{ Treatments } & \multicolumn{2}{|c|}{$\begin{array}{c}\text { Total } \\
\text { nitrogen } \\
(\%) \\
\end{array}$} & \multicolumn{2}{|c|}{$\begin{array}{c}\text { Total } \\
\text { phosphorus } \\
(\%) \\
\end{array}$} & \multicolumn{2}{|c|}{$\begin{array}{c}\text { Total } \\
\text { potassium } \\
(\%) \\
\end{array}$} \\
\hline & Initial & Final & Initial & Final & Initial & Final \\
\hline B1 & 1.61 & 1.73 & 0.27 & 0.32 & 1.02 & 1.22 \\
\hline B2 & 1.73 & 1.80 & 0.45 & 1.10 & 1.13 & 1.30 \\
\hline B3 & 1.85 & 1.97 & 0.56 & 1.25 & 1.20 & 1.39 \\
\hline B4 & 2.00 & 2.18 & 0.63 & 1.31 & 1.27 & 1.46 \\
\hline LSD 5\% & 0.57 & 0.51 & 0.22 & 0.18 & 0.32 & 0.179 \\
\hline
\end{tabular}

The results showed that the digestion of food wastes was increased at the end of the digestion period. This may be due to the consumption of total and volatile solids during anaerobic digestion to produce gases $\left(\mathrm{CH}_{4}\right.$ and $\left.\mathrm{CO}_{2}\right)$ and other products These results are in agreement with the findings of Estefanous et al. (2010) found that the concentrations of nitrogen, phosphorus, and potassium in the end product were increased, this may be due to a decrease in total solids. The percentage of phosphorus. potassium and total nitrogen were increased at the end of the fermentation period. This increase is likely to be due to the consumption of volatile solids during anaerobic digestion to produce gases $\left(\mathrm{CH}_{4}\right.$ and $\left.\mathrm{CO}_{2}\right)$ as reported El-Khayat (2019).

\subsection{Biogas and methane production rates}

The productivity of biogas and methane per unit of digester volume for both total solids and volatile solids added are presented in table (6). The B2 treatment showed higher productivity of biogas 36.53 liters than the recorded for B1 (28.56 liters), but they exhibited nearly almost productivity of methane 19.11 and 13.90 liters. Production rates both biogas and its methane content were indirect proportional to the concentrations of total and volatile solids loaded to the digesters therefore, the rates of biogas were decreased from 549.65 to 42.24 (L/kg VS added) relative to increase VS from B1 to B4 respectively.

Similarly, the B1 treatment showed a higher rate of methane production 267.51 (L/kg VS added ) than that calculated for B2 $(173.57 \mathrm{~L} / \mathrm{kg}$ VS added). While the biogas and methane production rates based on either total or volatile solids consumed were the highest in the case of B2 could be attributed to the high activity of lytic microorganisms. Cho et al. (1995) found that the methane yields of cooked meat, cellulose, boiled rice, fresh cabbage, and mixed food wastes were 482, 356, 294, 277 , and 427 liters $\mathrm{CH} 4 / \mathrm{kvolatile}$ solid added. In this respect, El-Akshar (2000) found that the biogas production rates per $\mathrm{kg}$ of volatile solids either added of consumed were $(215.33,826.47$ and 160.79, 797.79) for Jews mallow processing wastes and cattle dung respectively. Also, they found that the methane production rates per $\mathrm{kg}$ of volatile solids either added or consumed were $(123.84,475.31$ and 98.74, 489.88) for Jews mallow processing wastes and cattle dung respectively. The biogas and methane production rates were 420.68-liter biogas and 176.50-liter methane $/ \mathrm{kg}$ volatile solids added and 987.20-liter biogas and 706.00-liter methane $/ \mathrm{kg}$ VS consumed for municipal solid waste (Estefanous et al., 2010) 
Table 6: Solids destruction and production during anaerobic digestion of food wastes for 42 days

\begin{tabular}{|c|c|c|c|c|c|c|c|c|}
\hline \multirow{4}{*}{ Treatments } & \multicolumn{4}{|c|}{ Biogas production } & \multicolumn{4}{|c|}{ Methane production } \\
\hline & \multirow{3}{*}{$\begin{array}{c}\text { Total } \\
\text { biogas } \\
\text { production } \\
\text { L/digester }\end{array}$} & \multicolumn{3}{|c|}{$\begin{array}{c}\text { Rate of biogas production } \\
\text { (L / / g ) }\end{array}$} & \multirow{3}{*}{$\begin{array}{c}\text { Total } \\
\text { methane } \\
\text { production } \\
\text { (L) }\end{array}$} & \multicolumn{3}{|c|}{$\begin{array}{c}\text { Rate methane production } \\
\text { (L / Kg) }\end{array}$} \\
\hline & & \multirow{2}{*}{$\frac{\text { TS }}{\text { Add }}$} & \multicolumn{2}{|c|}{$\overline{V S}$} & & \multirow{2}{*}{$\begin{array}{c}\text { TS } \\
\text { Add }\end{array}$} & \multicolumn{2}{|c|}{ VS } \\
\hline & & & Add & Consumed & & & Add & Consumed \\
\hline B1 & 28.56 & 456.96 & 549.65 & 755.76 & 13.90 & 222.40 & 267.51 & 367.82 \\
\hline B2 & 36.53 & 292.24 & 331.79 & 958.79 & 19.11 & 152.88 & 173.57 & 501.57 \\
\hline B3 & 11.35 & 60.53 & 67.18 & 213.19 & 1.35 & 7.20 & 7.99 & 25.36 \\
\hline B4 & 9.62 & 38.48 & 42.24 & 141.76 & 0.91 & 3.64 & 4.00 & 13.41 \\
\hline LSD \%5 & 3.26 & 6.39 & 5.28 & 5.39 & 4.10 & 3.468 & 4.41 & 5.04 \\
\hline
\end{tabular}

\section{Biogas produced and it's component}

\subsection{Daily and cumulative biogas production.}

The daily production of biogas either liter/digester/day or liter/liter/day during the anaerobic digestion period (42 days) of food wastes waste are given in Figs (2 and 3).

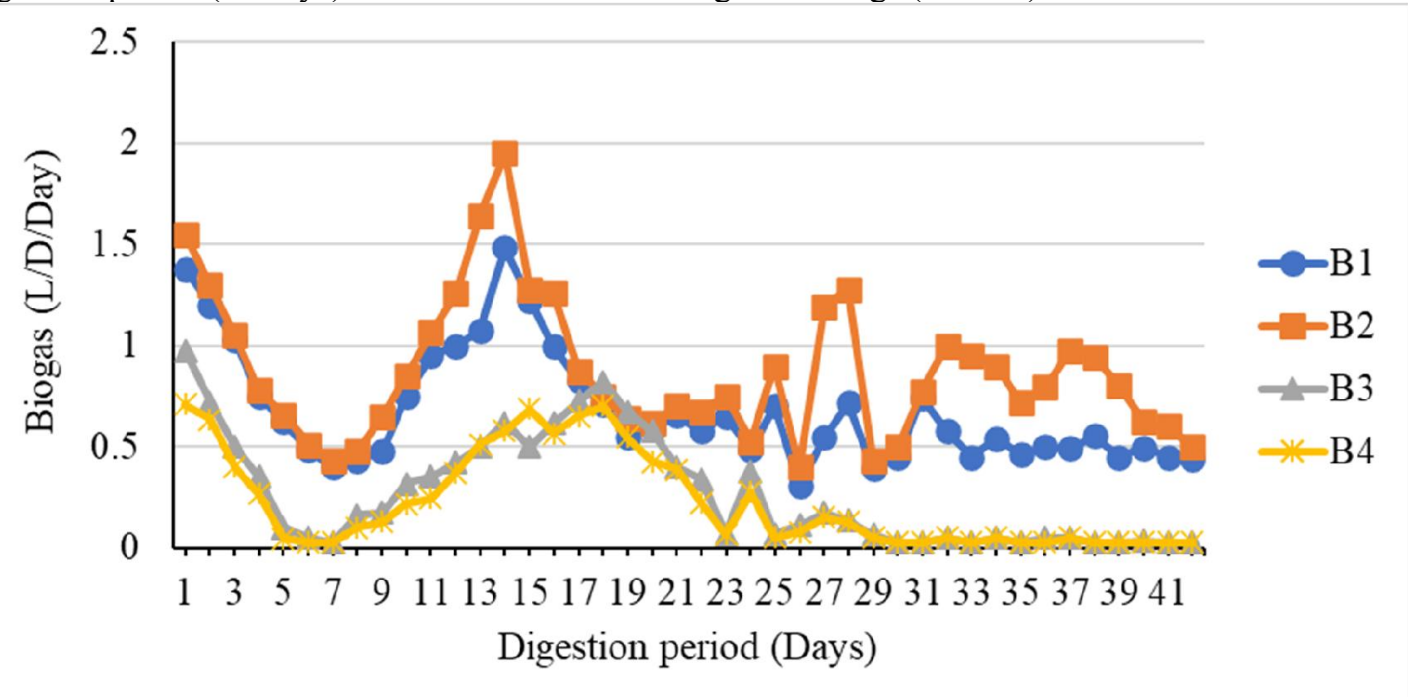

Fig. 2: Daily biogas production during anaerobic digestion of food wastes for 42 days.

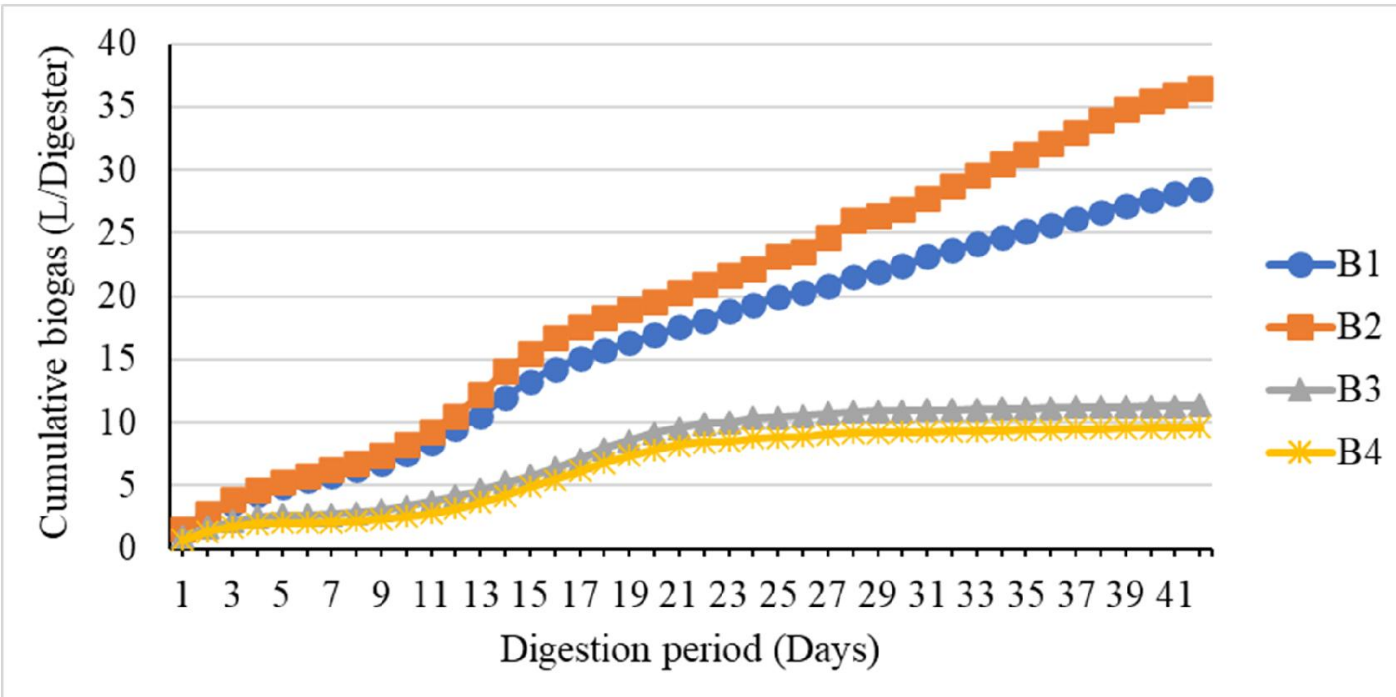

Fig. 3: Cumulative biogas production during anaerobic digestion of food wastes for 42 days. 
The achieved results indicated that the production of biogas started from the first day of anaerobic digestion and increased reached to the highest production at 14 days of anaerobic digestion, where it's recorded 1.485-1.950 liter/digest/day and $0.594-0.780$ liter/liter/day from B1,B2 respectively .while during 18 days it's recorded $0.825-0.700$ liter/digest/day and 0.328-0.280 liter/liter/day from B3,B4 respectively., and then slowly to reach the minimum level at the end of the digestion course. The cumulative biogas production recorded 28.555, 36.528, 11.350, and 9.615liter/digester from B1, B2, B3, and B4, respectively.

El-Housseini (1983) found that the garbage mixing with sewage sludge produced biogas within the first day whereas, moistening the garbage with water required 9 to 23 days to generate the biogas such period was needed for the proliferation of fermenting bacterial population's effective counts. Vindis et al. (2008) studied biogas production with the use of mini digester and reported that the highest biogas and methane yield was achieved in the case of ( $75 \%$ sugar beet $+25 \%$ maize). On contrary, the lowest biogas yield was in the case of ( $50 \%$ sugar beet $+50 \%$ maize), after twenty days the anaerobic digestion is mostly finished. However, after 35 days the amount of biogas was very low. Almoustapha et al. (2009) reported in their study that although biogas production began on the $8^{\text {th }}$ day, the gas became combustible only on the $11^{\text {th }}$ day. As of the $48^{\text {th }}$, the day the biogas production began to decline steadily. The total volume of biogas produced after 65 days was $151.4 \mathrm{~m}^{3}$, which is, $2.6 \mathrm{~m}^{3} /$ day. Budiyono et al. (2010) reported that biogas production was very slow at the beginning and the end period of observation.

\subsection{Daily and cumulative methane production}

Daily and cumulative methane during the production of digestion course are recorded in Figures (4 and 5).The methane gas was produced on a considerable amount after the first day of fermentation from the four mixtures of food wastes under consideration. The daily methane production either $\mathrm{L} / \mathrm{D} /$ day or L/L/day showed generally an increase up to about 14 days in $(\mathrm{B}, \mathrm{B} 2)$ and 18 days in (B3, B4) of the fermentation period.

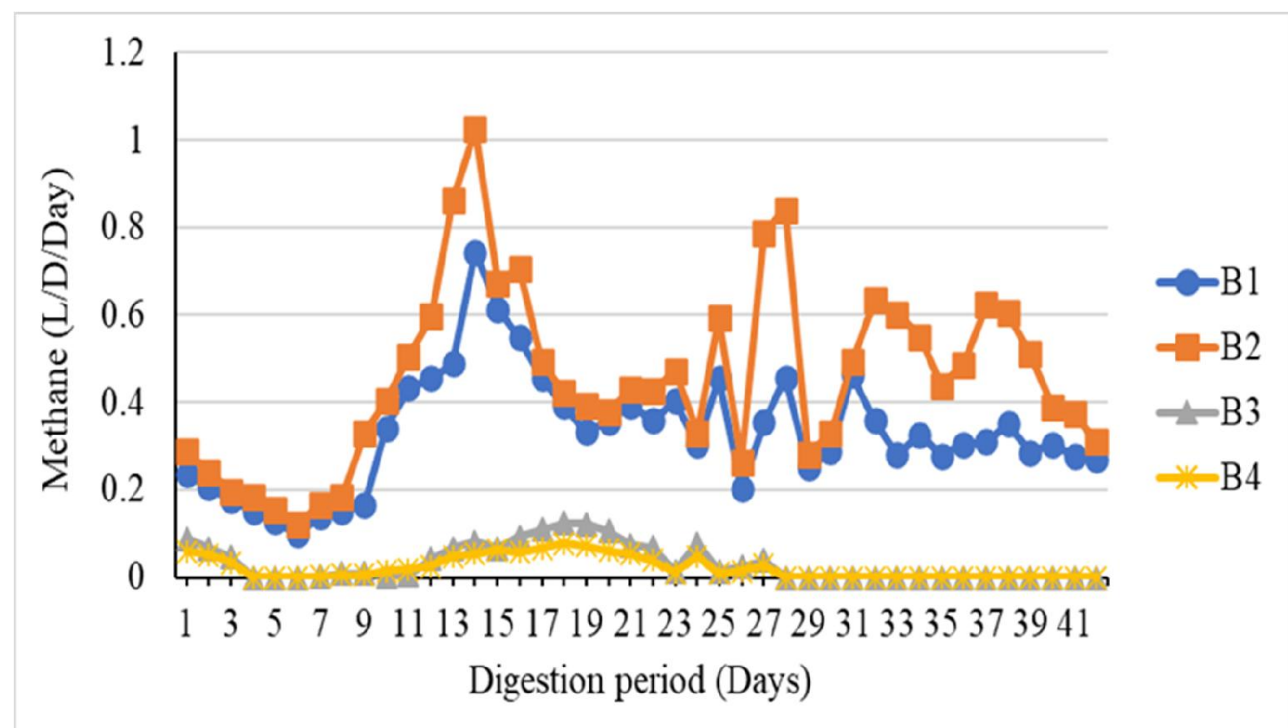

Fig. 4: Daily methane production during anaerobic digestion of food wastes for 42 days. 


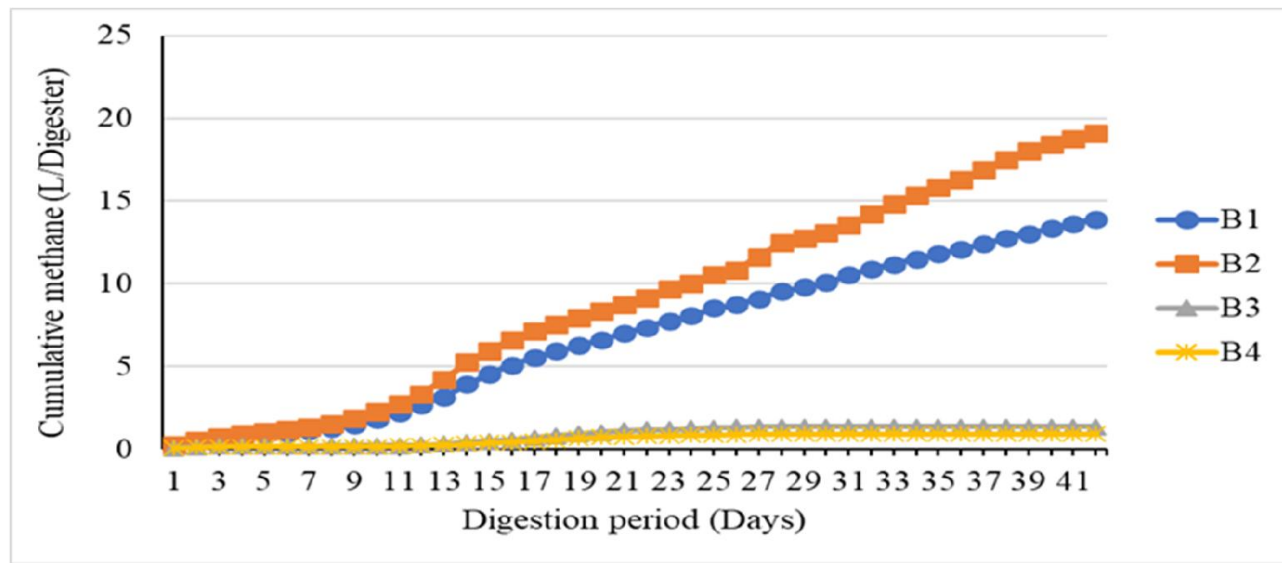

Fig. 5: Cumulative methane production during anaerobic digestion of food wastes for 42 days.

Daily methane production and cumulative were gradually decreased until the end of the experimental period. Data clearly show that the daily and cumulative methane production during anaerobic digestion was in the order from the highest to the lowest in B2, B1, B3, and B4. Estefanous et al. (1997) found that daily methane production and cumulative were gradually decreased until the end of the experimental period. Data clearly show that the daily and cumulative methane production during anaerobic $3^{\text {rd }}$ and $4^{\text {th }}$ week according to the type of digested waste and initial total solids. Amon et al. (2007) measured methane production at a commercial biogas plant for 1 year. Specific methane production was not constant throughout the year. When the dairy cattle diet changed from winter feed to summer feed, specific methane production increased. Winter feed consisted mainly of hay. In spring and summer fresh clover grass was fed. Kvasauskas and Baltrenas (2008) found that during the first several days, the amount of methane remained to drop due to the drop in temperature.

\subsection{Methane and Carbone dioxide gas quality}

The gas qualities were evaluated and the obtained results are presented in Figs. (6, 7 and 8$)$. The methane percentage in the produced biogas was gradually increased with the increasing fermentation period to until reached its maximum values at 27 days, where it's recorded 65.20, 66.00, 21.45 and $18.90 \%$ for B1, B2, B3 and B4, respectively. On the other hand, carbon dioxide $\left(\mathrm{CO}_{2}\right)$ percentages of the produced biogas were gradually decreased with increasing of fermentation period for B1 and B2 while B3 and B4 were increased at the end of fermentation could be attributed to the high activity of lytic microorganisms for organic matter to produce high levels of VFAs and low values of $\mathrm{pH}$.

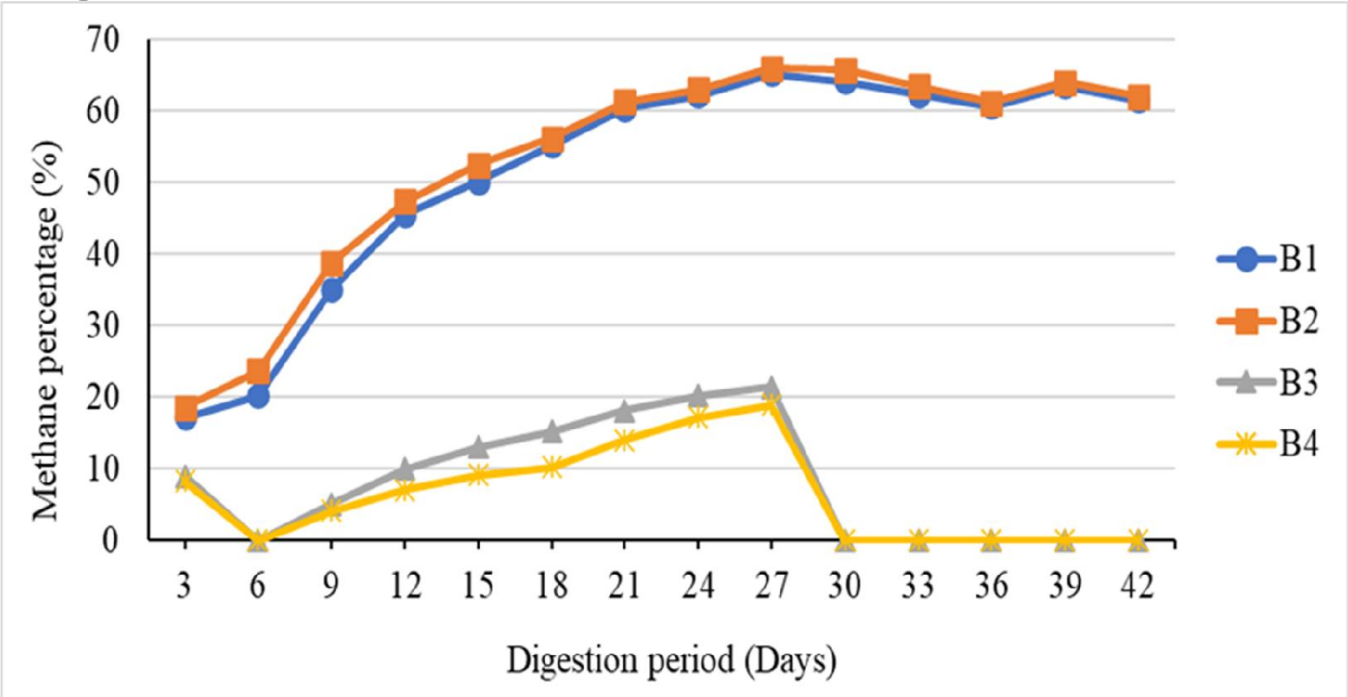

Fig. 6: Methane percentage during anaerobic digestion of food wastes for 42 days. 


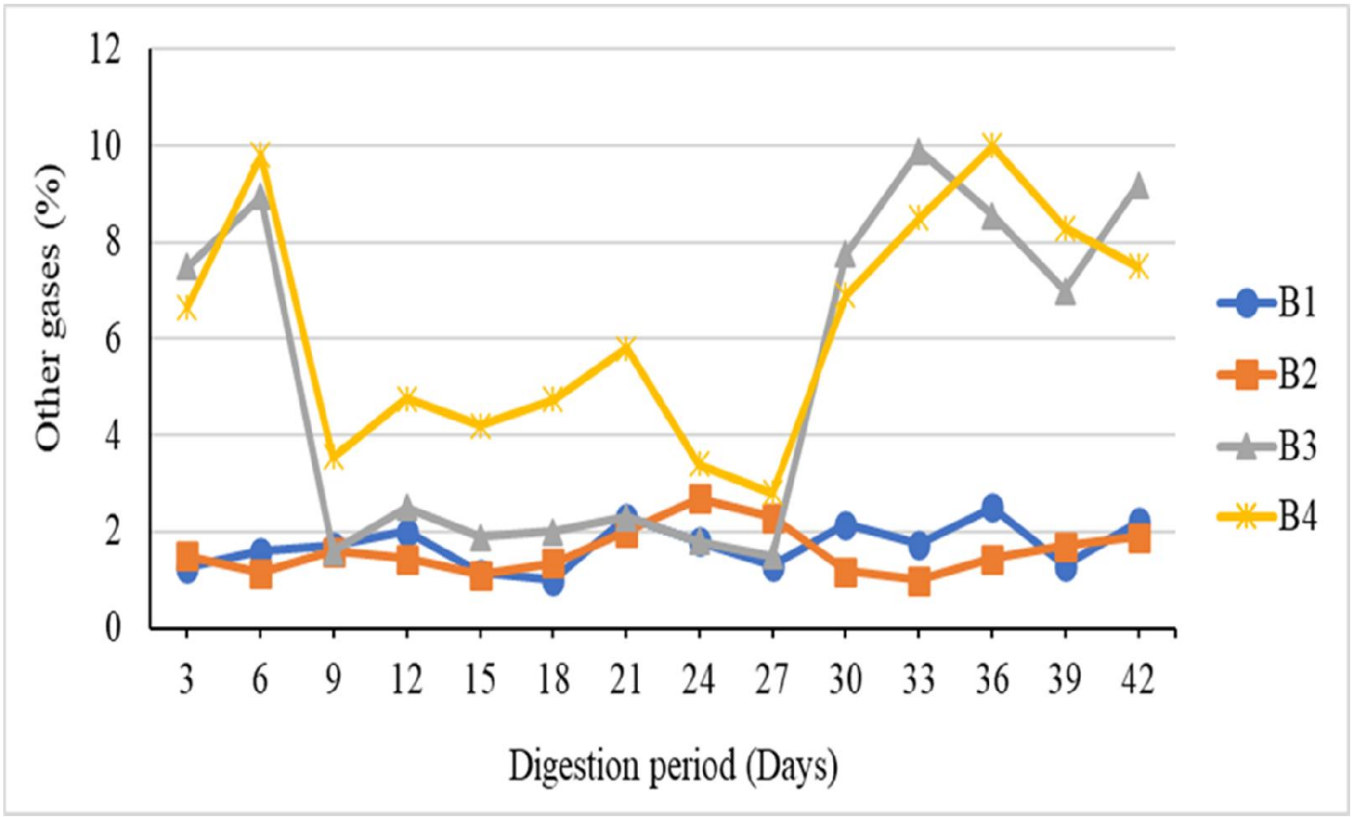

Fig. 7: Carbon dioxide percentage during anaerobic digestion of food wastes for 42 days



Fig. 8: Other gases percentage during anaerobic digestion of food wastes for 42 days.

Similar results were observed by many investigators. El-Akshar (2000); Estefanous et al. (2010) and El-Khayat (2014) found that the highest amount of biogas produced from Jew's mallow processing waste, mixed with cattle dung ranged between $60-70 \%$ methane and $25-30 \% \mathrm{CO}_{2}$ with small amounts of other gases $\left(\mathrm{H}_{2} \mathrm{~S}, \mathrm{H}_{2}, \mathrm{NH}_{3}\right.$, and $\mathrm{N}$ - oxides $)$.

\section{References}

Abbassi-Guendouz, A., D. Brockmann, E. Trably, C. Dumas, J.P. Delgenes, J.P. Steyer, and R. Escudie, 2012. Total solids content drives high solid anaerobic digestion via mass transfer limitation. Bioresour. Technol. 111: 55-61.

Almoustapha, O., S. Kenfack, and J. Millogo-Rasolodimby, 2009. Biogas production using water hyacinths to meet collective energy needs in a Sahelian country. Field Actions Sci. Rep. 2: $27-$ 32.

Amon, T., B. Amon, V. Kryvoruchko, W. Zollitsch, K. Mayer, and L. Gruber, 2007. Biogas production from maize and dairy cattle manure-Influence of biomass composition on the methane yield. Agriculture, Ecosystems \& Environment 118: 173-182. 
APHA, 1992. Standard methods for the examination of water and wastewater. $18^{\text {th }}$. American Public Health Association Washington, D.C., USA.

Black, C.A., D.O. Evans's, L.E. Ensmunger, J.L. White, F.E. Clark, and R.C. Dineure, 1981. Methods of Soil Analysis II, Chemical, and Microbiological Properties. American Soc. Argon. , Madison, Wisconsin, USA.

Budiyono, I.N., S. Johari, and Sunarso, 2010. The Influence of Total Solid Contents on Biogas Yield from Cattle Manure Using Rumen Fluid Inoculum. Energy Research Journal 1: 6-11.

Cho, J.K., S.C. Park, and H.N. Chang, 1995. Biochemical methane potential and solid-state anaerobic digestion of Korean food wastes. Bioresource Technology 52: 245-253.

Difco Manual, 1977. Difco Manual for dehydrated culture media and reagents $.8^{\text {th }}$ Edition. Difco Laboratories, Detroit, Michigan, U.S.A.

Dinsdale, R.M., F.R. Hawkes, and D.L. Hawkes, 1996. The mesophilic and thermophilic anaerobic digestion of coffee waste containing coffee grounds. Water Research 30: 371-377.

Duan, N., B. Dong, B. Wu, and X. Dai, 2012. High-solid anaerobic digestion of sewage sludge under mesophilic conditions: feasibility study. Bioresour Technol 104: 150-156.

El-Akshar, Y.S., 2000. Microbiological studies on anaerobic digestion of solid and liquid wastes. M.Sc. Thesis Fac. of Agric., Moshtohor, Zagazig University, Egypt.

El-Housseini, M., 1983. Fermentation of city refuses under anaerobic conditions. Ph. D .Thesis, Ain Shams Univ., Cairo, Egypt.

El-Khayat, R.M., 2019. Biochemical studies on anaerobic fermentation of some agricultural wastes. Ph. D. ,Thesis Fac. of Agric., Moshtohor, Beitha Univ.,Egypt.

El-Khayat, R.M., 2014. Biochemical studies on municipal solid waste to produce biogas and organic manure. M.Sc., Thesis Fac. of Agric., Moshtohor, Beitha Univ., Egypt.

Elmenofi, G.A.G., R. Capone, Shereen Waked, P. Debs, F. Bottalico, and H. El Bilali, 2015. An exploratory survey on household food waste in Egypt. Sixth International Scientific Agricultural Symposium, Agrosym, 1298-1304.

Estefanous, A.N., Y.S. El-Akshar, G.A.M. El-Sayed, and A.H. Amal, 2010. Anaerobic digestion of municipal solid waste to produce biogas and organic manure by using leachate recycling. Egypt. J. Biotechnol., 36: $65-80$.

Estefanous, A.N., S. Fahmy, F.T. Mikhaeel, and S.A. El- Shimi, 1997. Effect of aerobic pretreatment on anaerobic digestion of maize stalks. Proceeding of the 9th Conference of Microbiology, March, 25-27, Cairo, Egypt.

Forster-Carneiro, T., M. Perez, and L.I. Romero, 2008. Influence of total solid and inoculum contents on performance of anaerobic reactors treating food waste. Bioresour. Technol. 99: 6994-7002.

Guo, X., C. Wang, F. Sun, W. Zhu, and W. Wu, 2014. A comparison of microbial characteristics between the thermophilic and mesophilic anaerobic digesters exposed to elevated food waste loadings. Bioresour Technol 152: 420-428.

Hamilton, L.F., and G.S. Stephen, 1964. Quantitative chemical analysis. The Macmillan Company, New York, USA.

Kvasauskas, M. and P. Baltrènas, 2008. Anaerobic recycling of organic waste and recovery of biogas. Ekologija 54: 57-63.

Lay, J.J., Y.Y. Li, T. Noike, J. Endo, and S. Ishimoto, 1997. Analysis of environmental factors affecting methane production from high-solids organic waste. Water Science and Technology 36: 493-500.

Maramba, F.D., E.D. Obias, J. Banzon, C. Taganas, R. Alumbro, and Jr.A. Judan, 1978. Biogas and waste recycling: The Philippine experience. Liberty Flour Mills, Philippines.

Mussoline, W., G. Esposito, A. Giordano, and P. Lens, 2013. The anaerobic digestion of rice straw: A review. Crit. Rev. Environ. Sci. Tech. 43: 895-915.

Pavan, P., P. Battistoni, J. Mata-Alvarez, and F. Cecchi, 2000. Performance of thermophilic semi-dry anaerobic digestion process changing the feed biodegradability. Water Science and Technology 41: 75-81.

Snedecor, G. W. and W. G. Cochran, 1980. Statistical Method,7th.The Iowa State University Press, Ames., Iowa USA., P 504.

Ugwuoke, E.C., N.P. Nwachukwu, M.U. Ude, I. Ofili, and F.F. Abur, 2015. The effect of total solid concentration on biogas production. Inter. J. of Sci. Eng. and Technol. Res. 4: 3096-3099. 
Veeken, A., and B. Hamelers, 1999. Effect of temperature on hydrolysis rates of selected biowaste components. Bioresour. Technol., 69: 249-254.

Vindis, P., B. Mursec, C. Rozman, M. Janzekovic, and F. Cus, 2008. Biogas production with the use of mini digester. J. Achievements in Materials and Manufacturing Engineering, 99-102.

Wujick, W.J., and W.J. Jewell, 1980. Dry anaerobic fermentation. Biotechnology and Bioengineering Symp. No. 10, p. 43-65. Jon Willey \&Sons, Inc. N.Y., USA.

Zhang, C., H. Su, J. Baeyens, and T. Tan, 2014. Reviewing the anaerobic digestion of food waste for biogas production. Renewable and Sustainable Energy Reviews, 38: 383-392.

Zhang, C., H. Su, and T. Tan, 2013. Batch and semi-continuous anaerobic digestion of food waste in a dual solid-liquid system. Bioresour Technol 145: 10-16.

Zhang, L., Y.W. Lee, and D. Jahng, 2011. Anaerobic co-digestion of food waste and piggery wastewater: focusing on the role of trace elements. Bioresour Technol., 102: 5048-5059. 